\title{
Üniversite Öğrencilerinin Eş Seçim Tutumlarında Değer Yönelimlerinin Etkileri
}

DOI: $10.26466 /$ opus. 883241

*

\author{
Ali Ruhan Çelik* - Sevda Asqarova ** - Aylin Tutgun Ünal ${ }^{* * *}$ \\ * Doktora Öğrencisi, Üsküdar Üniversitesi, Sosyal Bilimler Enstitüsü, İstanbul / Türkiye \\ E-Posta: aliruhancelik@gmail.com \\ ORCID: $\underline{0000-0002-6147-5793}$ \\ ** Prof. Dr., Üsküdar Üniversitesi, Sağlık Bilimleri Fakültesi, İstanbul/ Türkiye \\ E-Posta: sevda.asqarova@uskudar.edu.tr \\ ORCID: 0000-0002-3469-9409 \\ *** Doç. Dr., Üsküdar Üniversitesi, İletişim Fakültesi, İstanbul/ Türkiye \\ E-Posta aylin.tutgununal@uskudar.edu.tr \\ ORCID: $\underline{0000-0003-2430-6322}$
}

\section{Öz}

İdeal eş kavramı, belirli standartları, varsayımları ve beklentileri oluşturmaktadır. Eş seçimi tercihlerini yönlendiren tecrübeler, eş seçimine yönelik tutumlara kaynaklık eder. Sinırlı tecrübelerden yola çıkarak edinilen ilişkiye yönelik inançlar ve bilgiler tutumlarm bilişsel yönünü oluşturur. Edinilen tecrübeler, değerlerde kimlik kazanmaktadır. Bu noktadan hareketle hazırlanan araştırmada üniversite öğrencilerinde eş seçim kriterlerinde değer yönelimlerinin etkisinin ortaya koyulması amaçlanmıştır. Bu amaç doğrultusunda değer yönelimlerinin eş seçim kriterlerinin beraber yaşama, yalnız ve tek doğru, aşk yeterli, çaba gösterme, idealleştirme, zıt kutuplar ve tam güven olmak üzere tüm faktörleri üzerinde anlaml etkisinin olduğuna yönelik yedi hipotez oluşturulmuştur. Araştırma var olan durumun belirlenebilmesini amaçladığından genel tarama modeline uygun olarak yürütülmü̈şür. Araştırmaya Üsküdar Üniversitesi'nde eğitim gören 222 lisans öğrencisi dahil edilmiştir. Öğrencilere sosyodemografik bilgi formu ile birlikte Romantizm ve Eş Tutum Ölçeği ve Portre Değerler Anketi uygulanmıştır. Araştırma bulgularında, araştırma hipotezleri regresyon analizi eşliğinde sorgulanmıştır. Araştırmadan elde edilen bulgulara göre üniversite öğrencilerinin değer yönelimlerinin eş seçim kriterlerinin beraber yaşama, yalnız ve tek doğru, aşk yeterli, çaba gösterme, idealleştirme, zıt kutuplar ve tam güven olmak üzere tüm faktörleri üzerinde anlaml etkisi vardır.

Anahtar Kelimeler: Üniversite Öğrencileri, Değer Yönelimleri, Eş Seçimi 
ISSN:2528-9527

E-ISSN: 2528-9535

YIl Year: 11

Cilt Volume: 17

Sayı Issue :38

Uluslararası Toplum Araştırmaları Dergisi International Journal of Society Researches

Haziran June 2021

Makalenin Geliş Tarihi Received Date: 19/01/2021

Makalenin Kabul Tarihi Accepted Date: 02/03/2021

\title{
The Effects of Value Orientations on Mate Choice Attitudes of University Students
}

*

\begin{abstract}
The concept of ideal spouse constitutes certain standards, assumptions and expectations. Experiences that guide mate choice preferences are based on attitudes towards partner selection. Religious beliefs and information obtained from limited experience lead to the cognitive orientation of attitudes. The composition of the experiences gained gains identity in social roles and values. The aim of this study is to determine the effect of value orientations on the selection criteria of university students. Seven hypotheses have been created that value orientations have a significant effect on all factors such as living together, lonely and only right, love is sufficient, effort, idealization, opposite poles and full trust. The research was carried out in a general survey model. A total of 222 undergraduate students studying at Üsküdar University were included in the research. Romantism and Portrait Values Questionnaire were applied to the students with sociodemographic information form. In the findings, the research hypotheses were tested with regression analysis. Findings from the research show value orientations have a significant effect on all factors of co-selection criteria, cohabitation, single and single correct, love sufficient, effort, idealization, opposite poles and full confidence.
\end{abstract}

Keywords: University students, Value Orientations, Mate Choice 


\section{Giriş}

Üniversite dönemi, bireylerin yaşamlarını değiştirebilecek fırsatlar ile yüzleştikleri bir dönemdir. Gençler bir yandan kariyer fırsatlarını değerlendirmekte diğer yandan yeni sosyal çevrelerine uyum sağlamaya çalışmaktadırlar. Erikson'a göre, yakın ilişkileri kurma ve geliştirme genç yetişkinler için önemli bir gelişimsel görevdir. Bireyin sosyal ilişkilerinin önemli bir bölümünü oluşturan yakın ilişkiler, birey için hem mutluluk hem de mutsuzluk kaynağı olabilmektedir. Bu dönemde yaşadıkları ilişkiler gençlerin karşı cinse yönelik tutumlarını etkileyebilmektedir (Erikson, 1998). Bu sayede, eş seçimi ve evlilik arifesindeki gençler bu konudaki beklentilerini değerlendirme fırsatı bulmaktadırlar.

Evlilik kararı kişinin tüm yaşamını etkilemesi bakımından oldukça önemlidir. Evliliklerin sağlıklı bir şekilde yürümesi ve evlilikten alınan doyumun yüksek olması, kişilerin uygun tercihler yapmasına bağlıdır. Eş seçimi kararı, kişinin, yaşamını kiminle sürdüreceğini, kimden çocuk sahibi olacağını, kiminle aile kuracağını belirlediği bir süreçtir. Bireyin yaşamına etkisi düşünüldüğünde oldukça önemli ve karmaşık bir karar alma sürecidir. Evlilik, insanoğlunun neslinin devam ettirmesini sağlayan bir birlikteliktir. Toplumsal yaşamın en küçük yapı taşı olan ailenin de temeli evlilik ile atılır. Ailede öğrenen, sosyalleşen ve hayata hazırlanan çocuk, sadece neslin değil kültürün de devamını sağlar. Türk Medeni Kanunu'na göre evlilik, sürekli ve tam bir hayat ortaklığının yaratılması amacıyla iki insanın yasal olarak geçerli ve makul bir şekilde birleşmesi olup, hukuki, ahlaki ve sosyal bir kurumdur (Türk Medeni Kanunu, 2001).

Eş seçimi tercihlerini yönlendiren tecrübeler, eş seçimine yönelik tutumlara kaynaklık eder. Sınırlı tecrübelerimizden yola çıkarak edindiğimiz ilişkiye yönelik inançlar ve bilgiler tutumlarımızın bilişsel yönünü oluşturur. İdeal eş kavramı, belirli standartları, varsayımları ve beklentileri oluşturmaktadır. Standartlar, eş adayında olması istenen özelliklerdir. Beklentiler; ilişki içerisindeki kişinin, karşıdaki kişinin davranış tarzına yönelik öngörülerdir. Varsayımlar ise ilişkinin şu anda nasıl olduğu ile ilgili öngörülerdir. Evliliğe dair gerçekçi olmayan inançlar, katı standartlara, hatalı varsayımlara ve rasyonel olmayan beklentilere dönüşerek tutumlarımızı oluşturmaktadır. Eş seçimine 
yönelik sınırlandırıcı inançlar ve beklentiler, evlilik ilişkilerinde sorunlara neden olabilmektedir.

Üniversite çağı, gençlerin eş seçme kriterlerinin ve evliliğe yönelik tutumlarının geliştiği bir dönemdir. Mevcut ilişki deneyimleri eş seçimi tercihlerinin belirginleşmesini sağlar. Eş seçimi tercihleri evlenecekleri kişilerde aradıkları özelliklerin idealize edilmesi ve istemedikleri özelliklerin daha da netleşmesiyle şekillenir. Kişisel deneyimler ve mevcut ilişkiler eş seçimine yönelik tutumların oluşmasında etkilidir. Allport (1935) tutumun üç temel özelliğini; (a) tecrübeyle organize edilen (b) tutuma bağlı olduğu tüm objelerin ve durumların varlığında hareket eden ve (c) pozitif veya negatif tepkiler için hazır olma ve hazırlanmak şeklinde açıklamıştır (Akt. Köklü, 1995). Tutumlar, uyum sağlayıcı fonksiyonlarının yanı sıra, bireylerin davranışını yönlendiren gizli değişkenlerdir. Tutumların incelenmesi bireyin eğilimlerinin önceden tahmin edilmesi yönünden önemli veriler sunmaktadır. Buna göre, tutumların üç bileşeni vardır. Bunlardan birincisi "Duyuşsal Öğe" olup, bir nesne ya da olaya yönelik olumlu ve olumsuz hislere dayanmaktadır. İkincisi, "Bilişsel Öğe" olup inançlara ve bilgilere dayanır. Üçüncüsü ise, "Davranışsal Öğedir" ve sözlü ya da eylemsi ifadeye dayanır (Baysal, 1981, s.123).

Tutumlarımızı oluşturan bilgiler ya da inançlar her zaman rasyonel olmayabilir. Rasyonel olmayan inançlar eş seçimi sürecinde de etkili olarak "ideal eş" e yönelik katı ve abartılı beklentilere dönüşebilir. Bu doğrultuda mit kavramı gündeme gelmektedir. Mitler, evliliği sınırlandırıcı inançlarımıza, tecrübelerimizden çıkardığımız yanlış sonuçlar kaynaklık etmektedir. Larson'a (1988) göre mit, gerçek olup olmadığıyla ilgili bir kanıt bulunmamasına rağmen, yaygın bir şekilde kabul gören inançlardır (Akt. Güngör ve diğ., 2011, s.181). Eş seçimi mitleri, bireyin eş seçimi tercihlerini olumsuz yönde etkileyebileceği için eş seçimini sınırlandırıcı inançlar olarak nitelendirilir. Mitleri destekleyen bilimsel kanitlar bulunmamasına rağmen pek çok insan mitlere inanmaktadır. "Evlenecek muhteşem insanı bulana kadar evlenmemeliyim," "Birlikte yaşam, bizi evliliğe hazırlar" ve "Sevgi yeter" gibi mitler, insanın evlilik konusundaki kararlarını, eşini ya da kendini pek sorgulamamasına neden olduğu için, bireyin yanlış kişiyle evlenmesine yol açabilmektedir (Larson, 2000). 
Bireyin yaşantısından edindiği sınırlı deneyimleri, aile içi ilişkileri ve arkadaşlık tecrübeleri, iletişim araçlarından edindiği bilgiler, mitlerin oluşumu ile ilişkili görülmektedir (Güngör ve diğ., 2011, s. 181). Çalışmalar gerçek dışı olan evlilik inançlarının, yakın ilişkilerde yaşanan doyumu azaltabildiğini göstermiştir. Larson (1992), eş seçimine yönelik 9 temel sınırlandırıcı inanç bahsetmektedir. Buna göre bu inançlar; tek ve yalnız bir ideal eş, mükemmel partner, mükemmel ilişki, mükemmel ben, daha fazla çaba, aşk yeterli, birlikte yaşama, karşıtı birbirini tamamlar ve seçim kolay olmalı inançlardır. Bu inançlar kişinin eş seçimine yönelik sağliklı karar vermesini engelleyen ve sınırlandıran inançlardır (Akt. Güngör ve diğ., 2011, s.181).

Ülkemizde 1945-1950 yılları arası toplumsal yapıdaki değişmenin başladığı dönemdir. Tarımda makineleşme, kırsal kesimden kentlere yapılan yoğun göçler, kadınların çalışma hayatına girmeleri, aile planlaması politikalarının yaygınlaşması, geniş aile tipinden çekirdek aile tipine dönüşüm sonucunda aile üyelerinin bireyci davranışlarının artması, toplumda yaşlının sahip olduğu statünün değerini yitirmesi, ailenin değişimini etkileyen gelişmelerdir. Toplumdaki dönüşüm, eş seçimi kararlarını da etkilemiştir. Görücü usulü eski yaygınlığını yitirmiş, kişilerin birbirlerini tanıyarak, flört ederek evlenme yaklaşımı yaygınlaşmıştır. Bu yaklaşım sayesinde bireylerin tercihleri ön plana çıkmıştır. Tanışarak evlenme, görücü usulünün otoriter tavrının getirdiği sorunları ortadan kaldırsa da yeni sakıncalar ortaya çıkmıştır. Eş seçme sürecinde çiftlerin arasındaki romantik çekimin yoğun olması, değerlendirme aşamasının mantık ölçülerinden uzaklaşmasına neden olabilir. Çiftler, birbirlerine hoş görünmek için olumsuz tavırlarını gizlemeye çalışmaktadırlar. Eş seçme kararının sağlıklı olabilmesi için çiftlerin birbirlerini akılcı ve gerçekçi bir tutumla değerlendirmeleri gereklidir (Özgüven, 2014, s.36).

Alanyazın incelendiğinde, üniversite gençliğinin evlilik hakkındaki tutumları ile ilgili pek çok araştırma yapılmaktadır. Yapılan güncel Türkiye Gençlik ve Aile araştırmasında önlisans, lisans ve lisansüstü düzeyde öğrenim gören ülkemizin yedi bölgesindeki devlet ve vakıf üniversitelerinden 18-35 yaş aralığında 3 bin 266 katılımcıya evlilik hakkındaki düşünceleri, hangi özelliklerdeki eş adayıyla evlenmek istedikleri, nasıl bir tören hayal ettikleri ve aile kurumuna yükledikleri 
anlam incelenmiştir. Buna göre gençlerin $\% 58,4^{\prime} \ddot{u}$ evliliğin mutlu bir beraberlik olduğunu, \%19,5'i sorumluluk, \%9,8'i aşk ve tensel uyum olduğunu belirtmiştir. Araştırmada gençlerin yarısından fazlasının aşk evliliği $(\% 64,3)$, bir kısmının mantık evliliği yapmak istediği $(\% 16,7)$, $\% 15,6$ oranındaki gencin ise evlilik düşünmediği ortaya çıkmıştır. Öğrencilerin görüşlerinden hareketle erkekler için ideal evlenme yaşı olarak 27-28 civarında çıkarken, kadınlarda bu yaşın 25-26 bandında olduğu saptanmıştır. Bununla birlikte, eş seçim kriterleri incelendiğinde, $\% 80,5$ 'inin iyi huylu olmasını, \%68,4'ünün ayn değerlere sahip olmasını, yüzde ellilerde seyreden oranda ise iyi bir aileden olmasını ve aynı dünya görüşünü paylaşmasını istediği bulunmuştur (Tarhan, 2020). Bu doğrultuda değer kavramının önemi bir kere daha gündeme gelmiştir.

\section{Değer Yönelimi}

Değer, bir insanın, beşerî özelliklerini, istek, niyet ve davranışlarını değerlendirirken başvurduğu kriterlerdir (Dilmaç, 1999, s.12). Değer kavramı; insanın amaçlarını ve hayata bakış açısını belirleyen, alınan kararlara etki eden, prensipleri oluşturan ve inançları yansıtan bir tercih (Aktepe ve Yel, 2009, s.608), çeşitli durumlarda, seçilen hayat tarzı, davranışları ve olayları yönlendiren, önem sırasına göre derecelendirilmiş görüş veya inançtır (Baloğlu ve Balgalmış, 2005). Değerler, davranışlara kaynaklık eden ve onları yargılamayı sağlayan anlayış olarak görülen, insanların neyi önemli gördüklerini tanımlayarak istekleri, arzu edilen ve edilmeyen durumları açıklayan (Erdem, 2003, s.56; Morsümbül, 2014), bireyin çevresiyle etkileşimi sonucunda içselleştirdiği, kişinin var olan seçeneklerden birini diğerlerinden üstün tutmasına yarayan, insanların yaptığı doğru-yanlış, iyi-kötü davranışları etkileyen ve bu davranışları anlamlandırmada başvurulan kriter ve standartlardır (Akbaş, 2004, s. 19).

Lawrance (2003) değerin bazen izafi, bazen açık bir şekilde tanımlanan, insanın kişiliğini, onun dahil olduğu gruba ait karakteristik özelliklerini, alternatiflerin arasından seçim yapma aşamasına etki eden ve faaliyetlerinin sonuçlarını belirleyen istekler ile alakalı olduğunu söylemektedir (Akt. Özmete, 2007, s.11). Rokeach (1973) ve Feather (1975) değer kavramını; bireylerin davranışlarına, ideolojilerine, kararlarına, kendilerini ifade etme biçimlerine, kendilerini diğer bireylerle 
karşılaştırmalarına, kendi davranışlarını değerlendirmelerine, diğer bireyleri etkileme girişimlerine ve davranışlarına açılık getirmelerine ve düşüncelerine rehberlik eden standartlar kümesidir, şeklinde tanımlanmaktadır. $\mathrm{Bu}$ tanımda değerlerin bireysel yönü vurgulanmaktadır (Feather, 1975; Rokeach, 1973).

Diğer yandan bazı araştırmalarda yaş özelliği göz önünde bulundurularak bireylerin belirli zaman dilimlerine ayrılmasıyla değer ve davranışlarının farklılaşması kuşak kavramı doğrultusunda açılanmaktadır (Akdemir ve diğerleri, 2013; Ekşili ve Antalyalı, 2016; Latif ve Serbest, 2014; Mücevher, 2015; Tutgun-Ünal ve Deniz, 2020; Yıldırım ve Becerikli, 2013). Buna göre dünya genelinde kabul gören ve ülkemizde de yaygınlaşan Baby Boomer, $X, Y$ ve $Z$ gibi birtakım kuşak adlandırmalarına göre bireylerin belirli yaş gruplarına ayrılarak değer ve davranışları teknoloji kullanımına, yaşadığı coğrafyaya, belirli bir zaman dilimindeki olaylar bütününe göre açıklandığına rastlanmaktadır (Berkup, 2014; Çetin Aydın ve Başol, 2014; Deniz ve Tutgun-Ünal, 2019; Özdemir, 2017; Toruntay, 2011).

İnsanlar ve değerler arasında bulunan ilişki karşılıklıdır. İnsanlar değerleri, değerler de insanları yaşatmaktadır. Fakat değerler fakirzengin, okuyan-okumayan, erkek-kadın, yaşlı-genç gibi pek çok sosyal kategoriye göre, farklı şekillerde algılanır. İnsan davranışları ve değerler arasında bulunan ilişki bire bir ve tek yönlü değildir. Değerlerin sosyal hayat içerisinde gerçekleşmesi karmaşık olan bir süreçtir (Aydın, 2003, s.125). Rugman ve Hodgetts (2001) sosyolojide değeri analiz ederken, toplum yapısı içinde bulunan rollerin, süreçlerin ve kurumların bilinmesi gerektiğini, bu rol, süreç ve kurumların anlamlandırılmasınınsa değerler aracılığı ile mümkün olacağını belirtir. İnsanların toplum içerisindeki davranışlarını düzenleyen ve gösteren bir yol haritası niteliğinde olan sosyal değerler, toplumdaki sosyal bütünlügü sağlayan ortak davranış kodları şeklindedir (Rugman ve Hodgetts, 2001).

Psikolojik açıdan değerler, kişiliğin şekillenmesi için gerekli olan öğelerin merkezinde yer alır. Psikologlar değerleri, genellikle erken yaşlarda gelişimsel süreçler aracılığıyla kazanılan bireylerin davranışsal tercihleri olarak tanımlar (Sağnak, 2004, s. 103). Misket (1985); psikolojide değerleri, davranışların devamlılığını ve düzenliliklerini anlamaya yarayan araçlar olması yönüyle açılamış ve değerleri tutum, karar 
verme, güdü, zekâ, ihtiyaç ve inanç gibi kavramlar ile alakalı olarak ele almıştır (Akt. Akbaş, 2004, s.51). Değerler psikolojisine göre değeri, bir şeyin arzu edilebilir ya da edilemez olduğu hakkındaki inanç olarak tanımlamak mümkündür. Bir inanç olması bakımından değer, dünyanın belirli kısmı ile alakalı bilgi, duygu ve idrakın bir terkibidir. Ancak değer, inancın özel bir biçimi olması nedeniyle ondan daha ileri olan bir zihin organizasyonu şeklindedir (Güngör, 2000, s.27).

Değerler bir toplumun işleyişini, bütünlügünü ve varlığını sürdürebilmek için üyelerin çoğu tarafından gerekli ve doğru oldukları kabul edilen, ortak amaç, düşünce, ahlâki ilke ve davranışlarını oluşturan inançlardır (Aktan ve Turan, 2008). Bir davranış şeklini bir başkasına tercih etme konusunda değerlerin rolü önemlidir. Başka bir bakış açısına göre değerler bilinçli ve amaçlı davranışların kaynağını oluşturmakta ve ölçütlerini belirlemektedir (Sarı, 2005, s.76). Herhangi bir toplum yapısının incelenmesine katkı sağlayacak en önemli faktör, o toplumun sahip olduğu değer yargılarının bilinmesidir. Bir toplumun geleceğe ilişkin yapısına ilişkin tahminlerdeki isabet ancak bu şekilde mümkün olmaktadır (Özensel, 2003).

Toplumun en küçük birimi olan aile, eğitim ve din gibi kurumların değerlerinin kabullenilmesinde ve öğrenilmesinde, bir sonraki nesle aktarılmasında oldukça önemlidir. Değerler ailenin, dolayısıyla da toplumun devamı için önemlidir. Ayrıca, bilindiği üzere bir toplumda değerlerin tanımlandığı temel mekanizmalar, bireyin üstlendiği sosyal görevlerdir. Bu görevler de toplumun sınıflaşma sistemiyle sosyal yapıyı meydana getiren sosyal süreçler ile yakından ilgilidir. Bir topluluktaki iyikötü kavramının belirlenmesi, uygun düşünme ve davranış sergileme yöntemlerinin tümü, değerler sayesinde olur. Bu şekilde, toplum içindeki ödüllendirme araçlarının ve sosyal denetleme mekanizmalarının değer temalı oldukları görülmektedir. Diğer taraftan bir toplumdaki değerlerin temeli, kişisel/toplumsal varlığın dışında olmaktadır. İnsanlar bunları denetleyemezler; çünkü bunlar, insanın denetleyemeyeceği çoğunlukta ve çeşitliliktedir (Özensel, 2003, s. 219).

Değerler; fiillerin içinde ve sonucunda yer alan, insan olgusu bulunan bütün olayların oluşmasında belirleyici etkendir. Tüm insani olgular bir değere dayanırlar. Davranışların bir amacı oldukları kadar sonucunu değerlendirmeyi sağlayan değerler, her şeyden önce bir ölçek görevine 
sahiptir. Değerleri inceleyen önemli araştırmacılardan birisi Schwartz olup, değerleri sınıflandırmıştır. Schwartz'a (1992) göre değerler tüm toplumu ve olayları değerlendirmek, fiillerini belirlemek ve meşrulaştırmak için kullandıkları ölçütlerdir. Schwartz, sinıflandırmasında 10 değer grubu belirlemiştir. Çeşitli değer beklentilerini saptamış ve her bir değeri kendi amaçlarını açıklayarak karakterize etmiştir. Bu değerler şunlardır (Schwartz, 1992):

- Güç; kaynaklar üzerinde hâkimiyeti ve toplumsal statüyü ifade etmektedir. Bu değer boyutunda bulunan değerler; otorite sahibi olmak, zengin olmak, toplumsal güç sahibi olmak ve toplumsal saygınlığ koruyabilmektir.

- Başarı; sosyal standartlara göre, kişinin başarılı olabilmesi için gerekli olan şeyleri yapmasını ifade eder. Hırs duygusu, zeki olmak ve sözünü geçirmek bu boyuta giren değerler arasında sayılır.

- Hazcılık; bireysel zevk ve lezzetlere odaklanmaktan ibarettir.

- Uyarılım; heyecanlı ve değişken bir hayat sürme, hayata meydan okuma ve yenilik arayışında bulunma duygusunu ifade eder.

- Özyönelim; düşünce ve eylemlerde özgür olma, üretkenlik, keşfetme ve merak duygusu gibi özellikleri içerir. Kendine saygılı olma esas olarak kabul edilir.

- Evrensellik; kendinden başka diğer varlıklara da değer vermeyi önemser. Doğayla iç içe olma, onu koruma ve iyiliğini düşünme önemli görülür. Tanıdık veya tanımadık tüm insanların mutluluğunu düşünme, hoşgörülü olma, insanları takdir etme, adalet, eşitlik ve barış içinde güzel bir dünya kurabilme bu değer boyutuna girmektedir.

- İyilikseverlik; insanlar arasındaki huzurun sürekliliğini, değerlerin artması için iyi ilişkiler kurulmasını ve yakın çevrenin iyiliğini düşünmesini ifade eder. Yardımsever, dürüst, bağışlayıcı, sadık ve sorumluluk sahibi olma bu değer boyutuna girmektedir.

- Geleneksellik; geleneksel kültüre, dinsel töre ve düşüncelere bağlılık ve saygıyı ifade eder. Saygı, hoşgörü, dindarlık, 1lımlılık ve dünyadan soyutlanmak bu boyuta girer.

- Uyma boyutunda; itaatkârlık, kendini kontrol altında tutma, kibarlık ve büyüklere saygı gibi değerler bulunur. Normları, sosyal 
beklentileri, muhalefeti ve diğerlerini üzmeye yönelik dürtü ve eylemlerin engellenmesini ifade eder.

- Güvenlik; bireyin kendisinin, ilişkilerinin ve toplumun ahengi ve kararlılığını ifade eder. Bu boyut; toplum düzenini, ailenin ve ulusun güvenliğini korumayı ve sürdürmeyi içerir.

Eş seçimi ile ilgili rehberlik çalışmalarına katkısı düşünüldügünde konu ile ilgili daha fazla araştırmaya gereksinim duyulmaktadır. Bu noktadan hareketle araştırmada üniversite öğrencilerinde eş seçim kriterlerinde değer yönelimlerinin etkisinin ortaya koyulması amaçlanmıştır. Amaç doğrultusunda araştırmada aşağıdaki hipotezler sorgulanmiştır.

- H1: Değer yönelimlerinin eş seçim kriterlerinden beraber yaşama faktörü üzerinde istatistiksel olarak anlamlı bir etkisi vardır.

- H2: Değer yönelimlerinin eş seçim kriterlerinden yalnız ve tek doğru faktörü üzerinde istatistiksel olarak anlamlı bir etkisi vardır.

- H3: Değer yönelimlerinin eş seçim kriterlerinden aşk yeterli faktörü üzerinde istatistiksel olarak anlamlı bir etkisi vardır.

- H4: Değer yönelimlerinin eş seçim kriterlerinden çaba göstermeme faktörü üzerinde istatistiksel olarak anlamlı bir etkisi vardır.

- H5: Değer yönelimlerinin eş seçim kriterlerinden idealleştirme faktörü üzerinde istatistiksel olarak anlamlı bir etkisi vardır.

- H6: Değer yönelimlerinin eş seçim kriterlerinden zit kutuplar faktörü üzerinde istatistiksel olarak anlamlı bir etkisi vardır.

- H7: Değer yönelimlerinin eş seçim kriterlerinden tam güven faktörü üzerinde istatistiksel olarak anlamlı bir etkisi vardır.

\section{Yöntem}

\subsection{Araştırmanın Modeli}

$\mathrm{Bu}$ araştırmada mevcut durumu tespit etme amaçlandığından niceliksel betimleme yöntemi doğrultusunda genel tarama modeline başvurulmuştur. Tarama modelleri, geçmişte ya da halen var olan bir durumu var olduğu şekliyle betimlemeyi amaçlayan araştırma yaklaşımlarıdır. Araştırmaya konu olan şey, birey ya da nesne, kendi 
koşulları içinde ve olduğu gibi tanımlanmaya çalışılır. Onları, herhangi bir şekilde değiştirme, etkileme çabası gösterilmez (Karasar, 2016).

\subsection{Evren ve Örneklem}

Araştırmanın evrenini 2017-2018 öğretim y1lında Üsküdar Üniversitesi'nde lisans eğitimi gören tüm öğrenciler oluşturmaktadır. Araştırma örneklemi olarak ise evren içerisinden basit rastgele örnekleme tekniği ile 111 kadın ve 111 erkek olmak üzere toplam 222 öğrenci seçilmiştir.

Tablo 1. Örnekleme ilişkin özellikler

\begin{tabular}{lll}
\hline & Frekans & Yüzde \\
\hline Cinsiyet & & \\
Kadın & 111 & 50.00 \\
Erkek & 111 & 50.00 \\
Yaş & & \\
19 yaş ve altı & 84 & 37.84 \\
20-22 yaş & 72 & 32.43 \\
23 yaş ve üzeri & 66 & 29.73 \\
Sinıf & & \\
1. sinıf & 96 & 43.24 \\
2. sınıf & 36 & 16.22 \\
3. sınıf & 60 & 27.03 \\
4. sinıf & 30 & 13.51 \\
Güncel bir ilişkiye sahip olma durumu & & \\
Evet & 114 & 51.35 \\
Hayır & 108 & 48.65 \\
Şu anki romantik ilişkiyi en iyi tanımlayan ifade & & \\
Flört & 78 & 78.30 \\
Söz/Nişan & 36 & 21.70 \\
Gelecekte evlilik düşünüyor ve/veya planlıyor musunuz? & & \\
Evet & 192 & 86.49 \\
Hayır & 30 & 13.51 \\
Evliliğin gerçekleşmesi için düşünülen en doğru yol & & \\
Flört ile karşllklı karar vererek & 156 & 70.27 \\
Tanışarak ailelerin karar vermesi ile & 66 & 29.73 \\
Anne eğitim düzeyi & & \\
İlköğretim & 96 & 43.24 \\
Lise & 60 & 27.03 \\
Üniversite & 66 & 29.73 \\
Baba eğitim düzeyi & & \\
\hline
\end{tabular}




\begin{tabular}{lll}
\hline & Frekans & Yüzde \\
\hline İlköğretim & 54 & 24.32 \\
Lise & 72 & 32.43 \\
Üniversite & 96 & 43.24 \\
Anne ve baba birliktelik durumu & & \\
Birlikte & 174 & 78.38 \\
\hline
\end{tabular}

Katılımciların \%50'si kadın, \%50'si erkektir. Buna göre, \%37,84'ü 19 yaşın altında, \%32,43' ü 20-22 yaş arasında, \%29,73'ü 23 yaş üzerindedir. Katılımciların \%43,24'ü 1. sinıf, \%16.22'si 2. sinıf, \%27.03'ü 3. sinıf, \%13.51'i 4. sinıf öğrencisidir.

Katılımclların \%51,35'i güncel bir ilişkiye sahiptir. Güncel ilişkiye sahip katılımcların \%78,30'u flört, \%21,70'i söz/nişan dönemindedir. Ayrıca katılımcıların \%86,49'u gelecekte evliliği düşünmektedir. Katılımcıların \%70,27'si eş adayıyla birlikte karar vermeyi, \%29,73'ü ailelerin karar vermesini evliliğin gerçekleşmesi için en doğru yol olarak görmektedir. Toplam ilişki süresinin ortalaması $3.21 \pm 2.76$ ' dır. En kısa ilişki süresi 1, en uzun ilişki süresi 9 yıldır.

Katılımcıların annelerinin \%43,24'ü ilköğretim, \%27.03'ü lise, \%29,73’ü üniversite eğitim düzeyine sahiptir. Katılımcların babalarının \%24.32'si ilköğretim, \%32,43'ü lise, \%43,24'ü üniversite eğitim düzeyine sahiptir. Ayrıca katılımcıların \%78,38' inin anne ve babası birlikte yaşamaktadır.

\subsection{Veri Toplama Araçları}

Araştırma verilerinin toplanmasında araştırmacılar tarafından oluşturulan anket formu kullanılmıştır. Kullanılan anket formunda Kişisel Bilgi Formu, Romantizm ve Eş Seçimi Tutum Ölçeği ve Portre Değerler Anketi olmak üzere 3 bölüm yer almaktadır. Bu bölümlere ilişkin bilgiler aşağıda alt başlıklar halinde verilmiştir.

2.2.1 Romantizm ve Eş Seçimi Tutum Ölçeği: Eş seçimine yönelik sinırlandırıcı inançları ölçmek amacıyla Cobb, Larson ve Watson tarafından 2003 yılında hazırlanmıştır. Ölçek, Güngör ve diğerleri tarafından 2011 yılında Türkçe'ye uyarlanmıştır. Ölçek, 32 maddeden ve 7 faktörden (Yalnız ve tek doğru, Aşk yeterli, Beraber yaşama, Tam güven, 
İdealleştirme, Çaba göstermeme, Zıt kutuplar) oluşmaktadır. Ölçeğin iç tutarlılık katsayısı 0,65 olarak hesaplanmıştır (Güngör ve diğg., 2011).

2.2.2 Portre Değerler Anketi: Araştırma grubunun değer yönelimlerini belirlemek için Schwartz ve diğerleri tarafından 2012 yılında geliştirilen 57 maddelik Portre Değerler Anketi (PDA57) kullanılmıştır. Ankette 19 farklı değer tipi üçer madde ile ölçülmektedir. Her madde hipotetik bir kişi için belli bir Şekilde davranmanın önemli olduğu biçiminde ifade edilen bir cümlelik portrelerden oluşmaktadır. Schwartz vd. ayrıca PDA57'nin yapı geçerliğini Türkçe uyarlamasını da içerecek şekilde farklı kültürlerde görgül olarak göstermişlerdir. Türkçe uyarlaması Demirutku ve Sümer (2010) tarafından yapılan ölçeğin, On dokuz değer tipi alt ölçeğinin test-tekrar test güvenirlikleri 48 ile 81 arasında değişmektedir.

\subsection{Verilerin Analizi}

Araştırma verilerinin analizinde SPSS 23 kullanılmıştır. Hipotezlerin sınanması sırasında öncelikli olarak değişkenler arasındaki ilişkinin ortaya koyulabilmesi için doğrusal regresyona yer verilmiştir.

\section{Bulgular}

Bu bölümde, araştırmanın amacı doğrultusunda oluşturulan hipotezlerin doğrulanmasına yönelik yapılan regresyon analizlerine göre bulgular yer almaktadır. Buna göre ilk olarak H1 hipotezi sorgulanmıştır.

H1: Değer yönelimlerinin eş seçim kriterlerinden beraber yaşama faktörü üzerinde istatistiksel olarak anlamlı bir etkisi vardır.

Tablo 2'de görüldüğü üzere, hipotezi test edebilmek amacıyla yapılan regresyon analizinde değer yönelimleri ile beraber yaşama arasında anlamlı bir etki söz konusudur $(\mathrm{p}<0,001)$. Beraber yaşamadaki değişimin \%69'u (Düzeltilmiş R2) modele dahil olan değer yönelimleri ölçeği tarafından açıklanmaktadır. Bu bulguya dayanarak H1 hipotezi kabul edilmiştir. Tabloda görüldüğü üzere modelde bağımsız değişken olarak bulunan değer yönelimleri ölçeğinin hazcılık, başarı, güç, güvenlik, 
geleneksellik, uyma, alçakgönüllülük, iyilikseverlik, evrenselcilik faktörlerinin, beraber yaşama üzerinde anlamlı etkisi bulunmaktadır (p1=0.000, p2 $=0.005, \mathrm{p} 3=0.037, \mathrm{p} 4=0.000, \mathrm{p} 5=0.000, \mathrm{p} 6=0.019, \mathrm{p} 7=0.000$ ， $\mathrm{p} 8=0.000, \mathrm{p} 9=0.001<0.050)$.

Tablo 2. Değer yönelimlerinin beraber yaşam üzerine etkisinin regresyon analizi

\begin{tabular}{lllllll}
\hline Bağımsız Değişken & $\beta$ & $\mathbf{t}$ & $\mathbf{p}$ & $\mathbf{F}$ & Model(p) & R2 \\
\hline Sabit & & 13.10 & .000 & & & \\
Özyönelim & 0.19 & 1.97 & .050 & 41.82 & 0.000 & 0.69 \\
Uyarılma & -0.01 & -0.18 & .859 & & & \\
Hazcılık & 0.28 & 4.94 & .000 & & & \\
Başarı Güç Saygınlık & 0.17 & 2.82 & .005 & & & \\
& -0.16 & -2.10 & .037 & & & \\
Güvenlik & -0.06 & -0.75 & .453 & & & \\
Geleneksellik & -0.29 & -3.56 & .000 & & \\
Uyma & -0.32 & -5.99 & .000 & & \\
Alçakgönüllülük & -0.20 & -2.36 & .019 & & & \\
İyilikseverlik & 0.39 & 7.22 & .000 & & & \\
Evrenselcilik & -0.69 & -6.47 & .000 & & & \\
\hline
\end{tabular}

Buna göre hazcllık puanındaki bir birimlik artışın, beraber yaşamada 0.28 ( $\beta 1)$ birimlik artış oluşturacağı söylenebilir. Başarı puanındaki bir birimlik artışın, beraber yaşamada 0.17 ( $\beta 2)$ birimlik artış oluşturacağ 1 söylenebilir. Güç puanındaki bir birimlik artışın, beraber yaşamada 0.16 ( $\beta 3)$ birimlik azalış oluşturacağ birimlik artışın, beraber yaşamada $0.29(\beta 4)$ birimlik azalış oluşturacağ söylenebilir. Geleneksellik puanındaki bir birimlik artışın, beraber yaşamada $0.32(\beta 5)$ birimlik azalış oluşturacağı söylenebilir.

Uyma puanındaki bir birimlik artışın, beraber yaşamada $0.20(\beta 6)$ birimlik azalış oluşturacağı söylenebilir. Alçakgönüllülük puanındaki bir birimlik artışın, beraber yaşamada $0.39(\beta 7)$ birimlik artış oluşturacağ1 söylenebilir. İyilikseverlik puanındaki bir birimlik artışın, beraber yaşamada $0.69(\beta 8)$ birimlik azalış oluşturacağı söylenebilir. Evrensellik puanındaki bir birimlik artışın, beraber yaşamada $0.27(\beta 9)$ birimlik artış oluşturacağ1 söylenebilir. 
H2: Değer yönelimlerinin eş seçim kriterlerinden yalnız ve tek doğru faktörü üzerinde istatistiksel olarak anlamlı bir etkisi vardır.

Tablo 3. Değer yönelimlerinin yalnız ve tek doğru üzerine etkisinin regresyon analizi

\begin{tabular}{lllllll}
\hline Bağımsız Değişken & $\beta$ & $\mathbf{t}$ & $\mathbf{p}$ & $\mathbf{F}$ & Model(p) & $\mathbf{R}^{2}$ \\
\hline Sabit & & 13.17 & .000 & & & \\
Özyönelim & -0.35 & -3.21 & .002 & & & \\
Uyarılma & -0.03 & -0.44 & .663 & & & \\
Hazcılık & -0.04 & -0.59 & .558 & & & \\
Başarı Güç & 0.43 & 6.22 & .000 & & & \\
Saygınlı & -0.01 & -0.15 & .878 & & \\
& 0.10 & 1.14 & .257 & 27.82 & 0.000 & \\
Güvenlik & -0.77 & -8.21 & .000 & & & \\
Geleneksellik & 0.38 & 6.24 & .000 & & & \\
Uyma & -0.51 & -5.35 & .000 & & & \\
Alçakgönüllülük & 0.62 & 10.12 & .000 & & & \\
İyilikseverlik & 0.28 & 2.27 & .024 & & & \\
Evrenselcilik & 0.33 & 3.49 & .001 & & & \\
\hline
\end{tabular}

Tablo 3'te görüldüğü üzere, hipotezi test edebilmek amacıyla yapılan regresyon analizinde değer yönelimleri ile yalnız ve tek doğru arasında anlamlı bir etki söz konusudur $(\mathrm{p}=0.000<0.050)$.

Yalnız ve tek doğrudaki değişimin \%59'u (Düzeltilmiş R2) modele dahil olan değer yönelimleri ölçeği tarafından açıklanmaktadır. Bu bulguya dayanarak H2 hipotezi kabul edilmiştir. Tabloda görüldüğü üzere modelde bağımsız değişken olarak bulunan değer yönelimleri ölçeğinin özyönelim, başarı, güvenlik, geleneksellik, uyma, alçakgönüllülük, iyilikseverlik, evrenselcilik faktörlerinin, yalnız ve tek doğruda anlamlı etkisi bulunmaktadır (p1=0.002, p2 $=0.000$, p3 $=0.000$, $\mathrm{p} 4=0.000, \mathrm{p} 5=0.000, \mathrm{p} 6=0.000, \mathrm{p} 7=0.024, \mathrm{p} 8=0.001<0.050)$. Buna göre özyönelim puanındaki bir birimlik artışın, yalnız ve tek doğruda 0.35 ( $\beta 1$ ) birimlik azalış oluşturacağı söylenebilir. Başarı puanındaki bir birimlik artışın, yalnız ve tek doğruda 0.43 ( $\beta 2$ ) birimlik artış oluşturacağ söylenebilir. Güvenlik puanındaki bir birimlik artışın, yalnız ve tek doğruda 0.77 ( $\beta 3$ ) birimlik azalış oluşturacağı söylenebilir. Geleneksellik puanındaki bir birimlik artışın, yalnız ve tek doğruda 0.38 ( $\beta 4$ ) birimlik artış oluşturacağı söylenebilir. Uyma puanındaki bir birimlik artışın, yalnız ve tek doğruda 0.51 ( $\beta 5$ ) birimlik azalış oluşturacağı söylenebilir. 
Alçakgönüllülük puanındaki bir birimlik artışın, yalnız ve tek doğruda 0.62 ( $\beta 6)$ birimlik artış oluşturacağı söylenebilir. İyilikseverlik puanındaki bir birimlik artışın, yalnız ve tek doğruda 0.28 ( $\beta 7)$ birimlik artış oluşturacağı söylenebilir. Evrenselcilik puanındaki bir birimlik artışın, yalnız ve tek doğruda 0.33 ( $\beta 8)$ birimlik artış oluşturacağı söylenebilir.

H3: Değer yönelimlerinin eş seçim kriterlerinden aşk yeterli faktörü üzerinde istatistiksel olarak anlamlı bir etkisi vardır.

Tablo 1. Değer yönelimlerinin aşk yeterli üzerine etkisine ilişkin regresyon analizi

\begin{tabular}{lllllll}
\hline Bağımsız Değişken & $\beta$ & $\mathbf{t}$ & $\mathbf{p}$ & $\mathbf{F}$ & Model(p) & $\mathbf{R}^{2}$ \\
\hline Sabit & & 2.61 & .010 & & & \\
Özyönelim & -0.08 & -0.73 & .468 & & & \\
Uyarılma & 0.14 & 1.95 & .052 & & & \\
Hazcılık & 0.51 & 8.04 & .000 & & & \\
Başarı Güç & -0.26 & -3.93 & .000 & & & \\
Saygınlık & -0.13 & -1.63 & .105 & & \multirow{2}{*}{0.000} & \\
Güvenlik & 0.41 & 5.03 & .000 & 31.40 & \\
Geleneksellik & -0.34 & -3.76 & .000 & & & \\
Uyma & 0.44 & 7.53 & .000 & & & \\
Alçakgönüllülük & 0.49 & 8.29 & .000 & & & \\
İyilikseverlik & -0.06 & -0.53 & .596 & & & \\
Evrenselcilik & -0.20 & -2.22 & .027 & & & \\
\hline
\end{tabular}

Tablo 4'te görüldüğü üzere, hipotezi test edebilmek amaciyla yapılan regresyon analizinde değer yönelimleri ile aşk yeterli arasında anlamlı bir etki söz konusudur $(\mathrm{p}<0,001)$.

Aşk yeterlideki değişimin \%62'si (Düzeltilmiş R2) modele dahil olan değer yönelimleri ölçeği tarafından açıklanmaktadır. Bu bulguya dayanarak H3 hipotezi kabul edilmiştir. Tabloda görüldüğü üzere modelde bağımsız değişken olarak bulunan değer yönelimleri ölçeğinin hazcılık, başarı, saygınlık, güvenlik, geleneksellik, alçakgönüllülük, evrenselcilik faktörlerinin, aşk yeterlide anlamlı etkisi bulunmaktadır (p1=0.000, p2=0.000, p3=0.000, p4=0.000, p5=0.000, p6=0.000, $\mathrm{p} 7=0.027<0.050)$. Buna göre hazcılık puanındaki bir birimlik artışın, aşk yeterlide 0.51 ( $\beta 1)$ birimlik artış oluşturacağı söylenebilir. Başarı 
puanındaki bir birimlik artışın, aşk yeterlide 0.26 ( $\beta 2)$ birimlik azalış oluşturacağı söylenebilir. Saygınlık puanındaki bir birimlik artışın, aşk yeterlide 0.41 ( $\beta 3$ ) birimlik artış oluşturacağı söylenebilir. Güvenlik puanındaki bir birimlik artışın, aşk yeterlide 0.34 ( $\beta 4$ ) birimlik azalış oluşturacağı söylenebilir. Geleneksellik puanındaki bir birimlik artışın, aşk yeterlide 0.44 ( $\beta 5)$ birimlik artış oluşturacağı söylenebilir. Alçakgönüllülük puanındaki bir birimlik artışın, aşk yeterlide 0.49 ( $\beta 6)$ birimlik artış oluşturacağı söylenebilir. Evrenselcilik puanındaki bir birimlik artışın, aşk yeterlide 0.20 ( $\beta 7)$ birimlik azalış oluşturacağ 1 söylenebilir.

H4: Değer yönelimlerinin eş seçim kriterlerinden çaba göstermeme faktörü üzerinde istatistiksel olarak anlamlı bir etkisi vardir.

Tablo 5. Değer yönelimlerinin çaba göstermeme üzerine etkisinin regresyon analizi

\begin{tabular}{lllllll}
\hline Bağımsız Değişken & $\beta$ & $\mathbf{t}$ & $\mathbf{p}$ & $\mathbf{F}$ & $\mathbf{M o d e l}(\mathbf{p})$ & $\mathbf{R}^{2}$ \\
\hline Sabit & & 3.48 & .001 & & & \\
Özyönelim & 0.02 & 0.17 & .863 & & & \\
Uyarılma & 0.25 & 3.20 & .002 & & & \\
Hazcılık & 0.32 & 4.84 & .000 & & & \\
Başarı Güç & 0.27 & 3.94 & .000 & & & \\
Saygınlık & 0.00 & 0.00 & .997 & & & \\
& 0.09 & 1.05 & .295 & 26.80 & 0.000 & \\
Güvenlik & 0.03 & 0.27 & .788 & & & \\
Geleneksellik & 0.22 & 3.63 & .000 & & & \\
Uyma & 0.02 & 0.21 & .831 & & & \\
Alçakgönüllülüik & 0.30 & 4.78 & .000 & & & \\
İyilikseverlik & -0.49 & -3.98 & .000 & & & \\
Evrenselcilik & -0.02 & -0.16 & .871 & & & \\
\hline
\end{tabular}

Tablo 5'te görüldüğü üzere, hipotezi test edebilmek amacıyla yapılan regresyon analizinde değer yönelimleri ile çaba göstermeme arasında anlamlı bir etki söz konusudur $(\mathrm{p}<0,001)$.

Çaba göstermemedeki değişimin \%58'i (Düzeltilmiş R2) modele dahil olan değer yönelimleri ölçeği tarafından açıklanmaktadır. Bu bulguya dayanarak H4 hipotezi kabul edilmiştir. Tabloda görüldüğü üzere modelde bağımsız değişken olarak bulunan değer yönelimleri ölçeğinin uyarılma, hazcılık, başarı, geleneksellik, alçakgönüllülük, iyilikseverlik faktörlerinin, çaba göstermemede anlamlı etkisi bulunmaktadır ( $\mathrm{p} 1=0.002$, 
$\mathrm{p} 2=0.000, \mathrm{p} 3=0.000, \mathrm{p} 4=0.000, \mathrm{p} 5=0.000, \mathrm{p} 6=0.000<0.050)$. Buna göre uyarılma puanındaki bir birimlik artışın, çaba göstermemede 0.25 ( $\beta 1)$ birimlik artış oluşturacağı söylenebilir. Hazcllık puanındaki bir birimlik artışın, çaba göstermemede 0.32 ( $\beta 2)$ birimlik azalış oluşturacağ 1 söylenebilir. Başarı puanındaki bir birimlik artışın, çaba göstermemede 0.27 ( $\beta 3$ ) birimlik artış oluşturacağı söylenebilir. Geleneksellik puanındaki bir birimlik artışın, çaba göstermemede 0.22 ( $\beta 4)$ birimlik artış oluşturacağı söylenebilir.

Alçakgönüllülük puanındaki bir birimlik artışın, çaba göstermemede 0.30 ( $\beta 5)$ birimlik artış oluşturacağı söylenebilir. İyilikseverlikte puanındaki bir birimlik artışı, çaba göstermemede 0.49 ( $\beta 6)$ birimlik azalış oluşturacağı söylenebilir.

H5: Değer yönelimlerinin eş seçim kriterlerinden idealleştirme faktörü üzerinde istatistiksel olarak anlamlı bir etkisi vardır.

Tablo 6. Değer yönelimlerinin idealleştirme üzerine etkisinin regresyon analizi

\begin{tabular}{lllllll}
\hline Bağımsız Değişken & $\beta$ & $\mathbf{t}$ & $\mathbf{p}$ & $\mathbf{F}$ & $\mathbf{M o d e l}(\mathbf{p})$ & $\mathbf{R}^{2}$ \\
\hline Sabit & & 8.24 & .000 & & & \\
Özyönelim & -0.59 & -4.18 & .000 & & & \\
Uyarılma & -0.08 & -0.84 & .400 & & & \\
Hazcilık & 0.40 & 4.73 & .000 & & & \\
Başarı & 0.26 & 2.90 & .004 & & & \\
Güç & 0.11 & 1.01 & .313 & & & \\
Saygınlık & 0.11 & 1.01 & .314 & 9.50 & 0.000 & 0.32 \\
Güvenlik & 0.10 & 0.86 & .390 & & & \\
Geleneksellik & 0.04 & 0.56 & .578 & & & \\
Uyma & -0.40 & -3.22 & .001 & & & \\
Alçakgönüllülük & 0.33 & 4.10 & .000 & & & \\
İyilikseverlik & 0.35 & 2.20 & .029 & & & \\
Evrenselcilik & -0.11 & -0.91 & .361 & & & \\
\hline
\end{tabular}

Tablo 6'da görüldüğü üzere, hipotezi test edebilmek amacıyla yapılan regresyon analizinde değer yönelimleri ile idealleştirme arasında anlamlı bir etki söz konusudur ( $\mathrm{p}=0.000<0.050)$.

İdealleştirmedeki değişimin \%32'si (Düzeltilmiş R2) modele dahil olan değer yönelimleri ölçeği tarafından açıklanmaktadır. Bu bulguya dayanarak H5 hipotezi kabul edilmiştir. Tabloda görüldüğü üzere modelde bağımsız değişken olarak bulunan değer yönelimleri ölçeğinin 
özyönelim, hazcılık, başarı, uyma, alçakgönüllülük, iyilikseverlik faktörlerinin, idealleştirmede anlamlı etkisi bulunmaktadır ( $\mathrm{p} 1=0.000$, $\mathrm{p} 2=0.000, \mathrm{p} 3=0.004, \mathrm{p} 4=0.001, \mathrm{p} 5=0.000, \mathrm{p} 6=0.029<0.050$ ). Buna göre özyönelim puanındaki bir birimlik artışın, idealleştirmede 0.59 ( $\beta 1)$ birimlik azalış oluşturacağı söylenebilir. Hazcılık puanındaki bir birimlik artışın, idealleştirmede 0.40 ( $\beta 2)$ birimlik artış oluşturacağı söylenebilir. Başarı puanındaki bir birimlik artışın, idealleştirmede 0.26 ( $\beta 3$ ) birimlik artış oluşturacağı söylenebilir. Uyma puanındaki bir birimlik artışın, idealleştirmede 0.40 ( $\beta 4)$ birimlik azalış oluşturacağı söylenebilir. Alçakgönüllülük puanındaki bir birimlik artışın, idealleştirmede 0.33 ( $\beta 5$ ) birimlik artış oluşturacağı söylenebilir. İyilikseverlikte puanındaki bir birimlik artışın, idealleştirmede 0.35 ( $\beta 6)$ birimlik artış oluşturacağ1 söylenebilir.

H6: Değer yönelimlerinin eş seçim kriterlerinden zıt kutuplar faktörü üzerinde istatistiksel olarak anlamlı bir etkisi vardır.

Tablo 7. Değer yönelimlerinin zıt kutuplar üzerine etkisinin regresyon analizi

\begin{tabular}{lllllll}
\hline Bağımsız Değişken & $\beta$ & $\mathbf{t}$ & $\mathbf{p}$ & $\mathbf{F}$ & $\mathbf{M o d e l}(\mathbf{p})$ & $\mathbf{R}^{2}$ \\
\hline Sabit & & 8.18 & .000 & & & \\
Özyönelim & -0.14 & -1.27 & .207 & 23.65 & 0.000 & 0.55 \\
Uyarılma & 0.06 & 0.70 & .487 & & & \\
Hazcılık & 0.35 & 5.10 & .000 & & & \\
Başarı Güç & 0.07 & 0.92 & .360 & & & \\
Saygınlık & 0.00 & 0.03 & .975 & & & \\
& 0.21 & 2.43 & .016 & & & \\
Güvenlik & -0.32 & -3.31 & .001 & & & \\
Geleneksellik & 0.30 & 4.68 & .000 & & & \\
Uyma & -0.26 & -2.57 & .011 & & & \\
Alçakgönüllülük & 0.45 & 6.97 & .000 & & & \\
İyilikseverlik & -0.68 & -5.30 & .000 & & & \\
Evrenselcilik & 0.60 & 6.15 & .000 & & & \\
\hline
\end{tabular}

Tablo 7'de görüldüğü üzere, hipotezi test edebilmek amacıyla yapılan regresyon analizinde değer yönelimleri ile zit kutuplar arasında anlamlı bir etki söz konusudur $(\mathrm{p}=0.000<0.050)$.

Ztt kutuplardaki değişimin \%55'i (Düzeltilmiş R2) modele dahil olan değer yönelimleri ölçeği tarafından açıklanmaktadır. Bu bulguya dayanarak H6 hipotezi kabul edilmiştir. Tabloda görüldüğü üzere 
modelde bağımsız değişken olarak bulunan değer yönelimleri ölçeğinin hazcılık, saygınlık, güvenlik, geleneksellik, uyma, alçakgönüllülük, iyilikseverlik, evrenselcilik faktörlerinin, zit kutuplarda anlamlı etkisi bulunmaktadir (p1=0.000, p2=0.016, p3=0.001, p4=0.000, p5 $=0.011$, $\mathrm{p} 6=0.000, \mathrm{p} 7=0.000, \mathrm{p} 8=0.000<0.050$ ). Buna göre özyönelim puanındaki bir birimlik artışın, zıt kutuplarda 0.35 ( $\beta 1)$ birimlik artış oluşturacağ 1 söylenebilir. Saygınlık puanındaki bir birimlik artışın, zıt kutuplarda 0.21 $(\beta 2)$ birimlik artış oluşturacağı söylenebilir. Güvenlik puanındaki bir birimlik artışın, zıt kutuplarda 0.32 ( $\beta 3$ ) birimlik azalış oluşturacağ 1 söylenebilir. Geleneksellik puanındaki bir birimlik artışın, zıt kutuplarda 0.30 ( $\beta 4)$ birimlik artış oluşturacağ 1 söylenebilir. Uyma puanındaki bir birimlik artışın, zıt kutuplarda 0.26 ( $\beta 5$ ) birimlik azalış oluşturacağ 1 söylenebilir. Alçakgönüllülük puanındaki bir birimlik artışın, zıt kutuplarda 0.45 ( $\beta 6$ ) birimlik artış oluşturacağı söylenebilir. İyilikseverlik puanındaki bir birimlik artışın, zıt kutuplarda 0.68 ( $\beta 7)$ birimlik azalış oluşturacağı söylenebilir. Evrenselcilik puanındaki bir birimlik artışın, zıtt kutuplarda 0.60 ( $\beta 8$ ) birimlik artış oluşturacağı söylenebilir.

H7: Değer yönelimlerinin eş seçim kriterlerinden tam güven faktörü üzerinde istatistiksel olarak anlamlı bir etkisi vardır.

Tablo 8'de görüldüğü üzere, hipotezi test edebilmek amaciyla yapılan regresyon analizinde değer yönelimleri ile tam güven arasında anlamlı bir etki söz konusudur $(\mathrm{p}=0.000<0.050)$.

Tam güvendeki değişimin \%52'si (Düzeltilmiş R2) modele dahil olan değer yönelimleri ölçeği tarafından açıklanmaktadır. Bu bulguya dayanarak H7 hipotezi kabul edilmiştir. Tabloda görüldüğü üzere modelde bağımsız değişken olarak bulunan değer yönelimleri ölçeğinin özyönelim, uyarılma, hazcılık, saygınlık, güvenlik, alçakgönüllülük faktörlerinin, tam güvende anlamlı etkisi bulunmaktadır ( $\mathrm{p} 1=0.000$, $\mathrm{p} 2=0.003, \mathrm{p} 3=0.000, \mathrm{p} 4=0.000, \mathrm{p} 5=0.000, \mathrm{p} 6=0.000<0.050)$. Buna göre özyönelim puanındaki bir birimlik artışın, tam güvende 0.66 ( $\beta 1)$ birimlik azalı̧̧ oluşturacağı söylenebilir. Uyarılma puanındaki bir birimlik artışın, tam güvende 0.25 ( $\beta 2)$ birimlik artış oluşturacağı söylenebilir. 
Tablo 8. Değer yönelimlerinin tam güven üzerine etkisine ilişkin regresyon analizi

\begin{tabular}{lllllll}
\hline Bağımsız Değişken & $\beta$ & $\mathbf{t}$ & $\mathbf{p}$ & $\mathbf{F}$ & Model(p) & $\mathbf{R}^{2}$ \\
\hline Sabit & & 12.81 & .000 & & & \\
Özyönelim & -0.66 & -5.58 & .000 & 21.00 & 0.000 & 0.52 \\
Uyarılma & 0.25 & 2.98 & .003 & & & \\
Hazcllı & 0.73 & 10.23 & .000 & & & \\
Başarı Güç & -0.11 & -1.45 & .149 & & & \\
Saygınlık & -0.05 & -0.55 & .583 & & & \\
& 0.35 & 3.81 & .000 & & & \\
Güvenlik & -0.39 & -3.84 & .000 & & & \\
Geleneksellik & 0.02 & 0.38 & .707 & & & \\
Uyma & 0.02 & 0.22 & .824 & & & \\
Alçakgönüllüllük & 0.24 & 3.64 & .000 & & & \\
İyilikseverlik & 0.01 & 0.11 & .911 & & & \\
Evrenselcilik & -0.09 & -0.87 & .383 & & & \\
\hline
\end{tabular}

Hazcılık puanındaki bir birimlik artışın, tam güvende 0.73 ( $\beta 3$ ) birimlik artış oluşturacağı söylenebilir. Saygınlık puanındaki bir birimlik artışın, tam güvende 0.35 ( $\beta 4$ ) birimlik artış oluşturacağı söylenebilir. Güvenlik puanındaki bir birimlik artışın, tam güvende 0.39 ( $\beta 5)$ birimlik azalış oluşturacağ1 söylenebilir. Alçakgönüllülük puanındaki bir birimlik artışın, tam güvende 0.24 ( $\beta 6$ ) birimlik artış oluşturacağı söylenebilir.

\section{Tartışma ve Sonuç}

Araştırmadan ulaşılan bulgulara göre, eş seçim kriterlerinden beraber yaşam üzerinde, değer yönelimlerinden hazcılık, başarı, alçakgönüllülük ve evrenselliğin pozitif, güç, güvenlik, geleneksellik, uyma ve iyilikseverliğin negatif etkisi; yalnız ve tek doğru üzerinde, başarı, geleneksellik, alçakgönüllülük, iyilikseverlik ve evrenselciliğin pozitif, özyönelim, güvenlik, uymanın negatif etkisi; aşk yeterli üzerinde, hazcılık, başarı, saygınlık, geleneksellik, alçakgönüllülüğün pozitif, başarı, güvenlik, evrenselciliğin negatif etkisi bulunmuştur. Bununla birlikte eş seçim kriterlerinden çaba göstermeme üzerinde, uyarılma, başarı, geleneksellik ve alçakgönüllülü̈̆ün pozitif, hazcılık ve iyilikseverliğin negatif; idealleştirme üzerinde, hazcılık, başarı, iyilikseverlik ve alçakgönüllülügün pozitif, özyönelim ve uymanın negatif etkisi mevcuttur. Bu durum gençlerin değer aktarımlarını yeniden gündeme getirmiştir. Alanyazın incelendiğinde, çekirdek aile kültürünün, 
bütün dünyadaki kuşaklar arası uçurumu büyüttüğü belirtilmekte olup klasik kültürün, kuşaklara aktarılamadığı vurgulanmaktadır (Apostolou, 2007; Güngör ve diğ., 2011; Hamarta ve diğ., 2015; Perilloux, Fleischman ve Buss, 2008; Tarhan, 2000). Elde edilen sonuçlar da bu durumu destekler niteliktedir.

Hamarta ve diğerlerinin (2015) 554 evli yetişkinden oluşan örneklemle yaptıkları çalışmanın bulgularının bizim bulgularımızı desteklediği görülmüştür. Buna göre araştırmada, Schwartz Değerler Listesi, Evlilikte Öz-yetkinlik Ölçeği ve Evlilik Yaşamı Ölçeği kullanılmış olup araştırma sonucunda, evlilik yaşamından duyulan tatminin, güç, uyarılma, yardımseverlik ve güven değerleri ile pozitif yönde anlamlı ilişkisi olduğu ortaya çıkmıştır. Ayrıca başarı, hazcılık, uyarılma, evrensellik, geleneksellik, uyum değerlerinin evlilik yaşamından duyulan tatmini tahminlediği görülmüştür.

Diğer bir bulgumuza göre ise eş seçim kriterlerinden zit kutuplar üzerinde, özyönelim, saygınlık, geleneksellik, alçakgönüllülük ve evrenselcilik pozitif, güvenlik, uyma ve iyilikseverliğin negatif; tam güven üzerinde, uyarılma, hazcılık, saygınlık ve alçakgönüllülüğün pozitif, özyönelim ve güvenliğin negatif etkisi olduğu görülmüştür. Bu bulgular kişilerin eş seçiminde toplumsal değerleri dikkate aldığını göstermektedir. Toplumsal kalıpların aile yaşantısını şekillendirdiği Türk toplumu gibi kapalı iklime sahip oryantalist kültürlerin üyelerinin, aile kurumunu oluştururken de sahip olduğu değerlere sahip kalması beklenen bir durumdur. Eş seçimi ile ilgili yapılan bazı araştırmalar, insanın evrimleşme sürecinde, ailelerin tercihlerinin çocuklara aktarılarak, onların eş seçme tercihleri üzerinde önemli etkileri olduğunu ortaya koymaktadır (Apostolou, 2007).

Araştırma sonucunda üniversite öğrencilerinin değer yönelimlerinin eş seçim kriterlerinin beraber yaşama, yalnız ve tek doğru, aşk yeterli, çaba gösterme, idealleştirme, zıt kutuplar ve tam güven olmak üzere tüm faktörleri üzerinde anlamlı etkisinin olduğu belirlenmiştir 


\title{
EXTENDED ABSTRACT
}

\section{The Effects of Value Orientations on Mate Choice Attitudes of University Students}

\author{
Ali Ruhan Çelik - Sevda Asqarova \\ Üsküdar University
}

Marriage decision is very important since it affects the whole life of the person. Healthy marriages and high marital satisfaction depend on people making appropriate choices. The decision of choosing a mate is a process in which the person determines whom to live with and with whom to establish a family. Considering its impact on an individual's life, it is a very important and complex decision-making process. The university age is a period in which the mate choice criteria and marriage attitudes are developed. Therefore, the attitudes of university students towards marriage and family institution are frequently examined in much research.

The attributed meaning towards family institution was analyzed by asking 3266 participants between the ages of 18-35 about their thoughts towards marriage, the qualifications they look for in a spouse candidate and what kind of ceremony they imagine in the "Turkey Youth and Family Survey". Accordingly, 58.4\% of the youth stated that marriage means a happy togetherness, $19.5 \%$ of them stated that it means responsibility, $9.8 \%$ of them stated that it means love and sensual harmony. It was revealed in the study that more than half of the young people $(64.3 \%)$ wanted to make a love marriage, some of them wanted to make a convenience marriage $(16.7 \%)$, and $15.6 \%$ of the youth did not intend to marry. Based on the student's opinions, it was determined that the ideal marriage age for men was around 27-28, while it was found to be in the ages of 25-26 for women. However, when the spouse selection criteria were examined, it was found that $80.5 \%$ of them $80.5 \%$ wanted the spouse to be well-mannered, $68.4 \%$ wanted the spouse to share the same values, and about $50 \%$ wanted the spouse to be from a good family and share the same world view (Tarhan, 2020). Thereby, the importance of the concept of value has once again come to the fore. 
The foundation of the family, which is the smallest building block of social life, is laid with marriage. It is very important in accepting and learning the values of institutions such as family, education and religion, and transferring them to the next generations. The child, who learns, socializes and prepares for life in the family, ensures the continuation of not only the generation but also the culture. Thus, family values are determinants of the social structure. Considering its contribution to the studies on spouse selection, more research is needed on the subject. From this point of view, it is aimed to reveal the effect of value orientations on spouse selection criteria in university students. In line with this purpose, some hypotheses were questioned in the study: "H1: Value orientations have a statistically significant effect on the coexistence factor among the spouse selection criteria", "H2: Value orientations have a statistically significant effect on the only true factor among the spouse selection criteria", "H3: Value orientations have a statistically significant effect on the love is sufficient factor among the spouse selection criteria", "H4: Value orientations have a statistically significant effect on the effortlessness factor among the spouse selection criteria", "H5: Value orientations have a statistically significant effect on the idealization factor among the spouse selection criteria", "H6: Value orientations have a statistically significant effect on the opposite poles factor among the spouse selection criteria", "H7: Value orientations have a statistically significant effect on the full trust factor among the spouse selection criteria".

Since it was aimed to determine the current situation, in accordance with the quantitative descriptive method, general screening model was used in this study. The population of the research consists of all students studying at Üsküdar University in the 2017-2018 academic year. As for the research sample, a total of 222 students, 111 females and 111 males, were selected from the population using the simple random sampling technique. $50 \%$ of the participants are women and $50 \%$ are men. $37.84 \%$ are under 19 years old, $32.43 \%$ are between $20-22$ years old, $29.73 \%$ are over 23 years old. $43.24 \%$ of the participants are 1 st year students, $16.22 \%$ are 2 nd year students, $27.03 \%$ are 3 rd year students and $13.51 \%$ are 4 th year students. A questionnaire form created by the researchers was used to collect research da ta. There are 3 sections in the questionnaire form 
used, namely Personal Information Form, Romance and Spouse Selection Attitude Scale and Portrait Values Questionnaire. During the testing of the hypotheses, linear regression has been used primarily to reveal the relationship between variables.

According to the findings of the research, it was found that hedonism, success, humility and universality from value orientations had a positive effect whereas power, security, traditionalism, conformity and benevolence had a negative effect on the coexistence factor among the spouse selection criteria. Further, the positive effect of success, traditionalism, humility, benevolence, universality and the negative effect of self-orientation, security, conformity on the only true factor was observed. In addition to these, the positive effect of arousal, success, traditionalism, humility and the negative effect of hedonism, benevolence on the effortlessness factor; the positive effect of hedonism, success, benevolence, humility and the negative effect of self-orientation, conformity on the idealization factor was found. According to another finding, the positive effect of self-orientation, respectability, traditionalism, humility, universality and the negative effect of security, conformity benevolence on the opposite poles factor; the positive effect of arousal, hedonism, respectability, humility and the negative effect of selforientation, security on the full trust factor was observed. These findings show that people take social values into account in the selection of a spouse. It is expected that members of orientalist cultures with a closed climate, such as Turkish society, where social patterns shape family life, take into account the values they have while establishing the family institution.

\section{Kaynakça / References}

Akbaş, O. (2004). Türk Milli Ĕ̆itim sisteminin duyuşsal amaçlarmın ilköğretim ikinci kademedeki gerçekleşme derecesinin değerlendirilmesi. Yayımlanmamış Doktora Tezi, Gazi Üniversitesi Eğitim Bilimleri Enstitüsü, Ankara.

Akdemir, A., Konakay, G., Demirkaya, H., Noyan, A., Demir, B., Ağ, C. vd. (2013). Y kuşağının kariyer algısı, kariyer değişimi ve liderlik tarzı beklentilerinin araştırılması. Ekonomi ve Yönetim Araştırmaları Dergisi, 2(2), 11-42. 
Aktan, D. ve Turan, S. (2008). Okul hayatında var olan ve olması düşünülen sosyal değerler. Türk Eğitim Bilimleri Dergisi, 6(2), 227-259.

Aktepe, V. ve Yel, S. (2009). İlköğretim öğretmenlerinin değer yargılarının betimlenmesi: Kırşehir ili örneği. Türk Eğitim Bilimleri Dergisi, 7(3), 607- 622.

Apostolou, M. (2007). Sexual selection under parental choice: The role of parents in the evolution of human mating. Evolution and Human Behavior, 28(6), 403-409.

Aydın, M. (2003). Gençliğin değer algısı: Konya örneği. Değerler Eğitimi Dergisi, 1(3), 121-144.

Baloğlu, M. ve Balgalmıs, E. (2005). İlköğretim ve Ortaöğretim yöneticilerinin öz-değerlerinin betimlenmesi. Değerler Eğitimi Dergisi, 3(10), 19-31.

Baysal, A.C. (1981). Sosyal psikolojide tutumlar. İstanbul Üniversitesi İşletme Fakültesi, İstanbul.

Berkup, S. B. (2014). Working with generations $X$ and $Y$ in generation $Z$ period: Management of different generations in business life. Mediterranean Journal of Social Sciences, 5(19), 218-229.

Cobb, N. P., Larson, J. H. ve Watson, W. L. (2003). Development of the attitudes about romance and mate selection scale. Family Relations, 52, 222-231.

Çetin Aydın, G. ve Başol, O. (2014). X ve Y kuşağı: Çalışmanın anlamında bir değişme var mı?, EJOVOC (Electronic Journal of Vocational Colleges), 4(4), 1-15. http://dx.doi.org/10.17339/ejovoc.41369

Deniz, L. ve Tutgun-Ünal, A. (2019). Sosyal medya çağında kuşakların sosyal medya kullanımı ve değerlerine yönelik bir dizi ölçek geliştirme çalışması. OPUS-Uluslararası Toplum Araştırmaları Dergisi, 11(18), 1025-1057.

Demirutku, K. ve Sümer, N. (2010). Temel değerlerin ölçümü: portre değerler anketinin Türkçe uyarlaması. Türk Psikoloji Yazıları, 13(25), 17-25.

Dilmaç, B. (1999). Ilköğretim öğrencilerine insani değerler eğitimi verilmesi ve ahlaki olgunluk ölçeği ile sınanması. Yayımlanmamış Yüksek Lisans Tezi, Marmara Üniversitesi Eğitim Bilimleri Enstitüsü, İstanbul.

Erdem, A.R. (2003). Üniversite kültüründe önemli bir unsur: Değerler. Değerler Ĕ̆itimi Dergisi, 1, 4-10.

Erikson, E. (1998). Life cycle completed: Extended version. New York: WW Norton \& Company.

Feather, N.T. (1975). Values in education and society. New York: The Free Press. 
Güngör, E. (2000). Değerler psikolojisi üzerine araştırmalar. (3.bs). İstanbul: Ötüken Yayınları.

Güngör, H. C., Yılmaz, M. ve Çelik, B.S., (2011). Romantizm ve eş seçim tutum ölçeğinin uyarlanması geçerlik ve güvenirlik çalışması. Türk Psikolojik Danışma ve Rehberlik Dergisi, 4(36), 180-190.

Hamarta, E., Deniz, M., Dilmaç, B. ve Arslan, C. (2015). A study on marital relationship and marital life satisfaction with regard to values of marital couples. International Journal of Human Sciences, 2(1), 55-69.

Ekşili, N. ve Antalyalı, Ö.L. (2017). Türkiye'de Y kuşağı özelliklerini belirlemeye yönelik bir çalışma: Okul yöneticileri üzerine bir araştırma. Humanities Sciences (NWSAHS), 12(3), 90-111, http://dx.doi.org/10.12739/NWSA.2017.12.3.4C0219

Karasar, N. (2016). Bilimsel araştırma yöntemleri: Kavramlar, teknikler ve ilkeler (35. bs.). Ankara: Nobel Yayınevi

Köklü, N. (1995). Tutumların ölçülmesi ve likert tipi ölçeklerde kullanılan seçenekler. Ankara Üniversitesi Ĕ̆itim Bilimleri Fakültesi Dergisi, 28(2), 81-83.

Larson, J. H. (2000). Should we stay together?. San Francisco: Jossey-Bass A Willey Company.

Latif, H. ve Serbest, S. (2014). Türkiye'de 2000 kuşağı ve 2000 kuşağının iş ve çalışma anlayışı. Gençlik Araştırmaları Dergisi, 2(4), 132-163.

Morsümbül, Ş. (2014). Kültürel değerlerin üç kuşak arasındaki değişimi üzerine bir inceleme: Ankara örneği. Hacettepe Üniversitesi Türkiyat Araştırmaları Dergisi, 21, 137-160.

Mücevher, M. H. (2015). X ve Y kuşağının birbirlerine karşı özellik ve etkileşim algıları: SDÜ örneği. Yayımlanmamış Yüksek Lisans Tezi, Süleyman Demirel Üniversitesi, Isparta.

Özdemir, Ş. (2017). Kuşaklar teorisine göre Türkiye'deki gençlerin medya kullanım alışkanlıkları ve İstanbul örneği. Yayımlanmamış Yüksek Lisans Tezi, Marmara Üniversitesi, İstanbul.

Özensel, E. (2003). Sosyolojik bir olgu olarak değer. Değgerler Ĕ̆itimi Dergisi, 1(3), 217239.

Özgüven, İ. E. (2014). Evlilik ve aile terapisi. Ankara: Nobel Yayınları.

Özmete, E. (2007). İş yaşamında değerler. İstanbul: Kedim Yayıncılık.

Perilloux, C., Fleischman, D. S. ve Buss, D. M. (2008). The daughter-guarding hypothesis: parental influence on, and emotional reactions to, offspring's mating behavior. Evolutionary Psychology, 6(2), 217-233. 
Rokeach, M. (1973). The nature of human values. New York: Free Press.

Rugman, A. ve Hodgetts, R. (2001). The end of global strategy. European Management Journal, 19(4), 333-343.

Sağnak, M. (2003). Illköğretim okullarında görevli yönetici ve öğretmenlerin örgütsel değerlere ilişkin algılar ile kişisel değerleri arasındaki uyum düzeyleri. Yayımlanmamış Doktora Tezi, Abant İzzet Baysal Üniversitesi, Bolu.

Sağnak, M. (2004). Örgütlerde değerler yönünden birey-örgüt uyumu ve sonuçları. Kuram ve Uygulamada Ĕ̆itim Yönetimi, 10(37), 72-95.

Sarı, E. (2005). Öğretmen adaylarının değer tercihleri: Giresun eğitim fakültesi örneği. Değerler Ĕ̆itimi Dergisi, 3(10),73-88.

Schwartz, S. H. (1992). Universals in the content and structure of values: Theory and empirical tests in 20 countries. Advances in experimental social psychology, 25, 1-65.

Schwartz, S. H., Cieciuch, J., Vecchione, M., Davidov, E., Fischer, R., Beierlein, C., Ramos, A., Verkasalo, M., Lönnqvist, J.-E., Demirutku, K., DirilenGumus, O. ve Konty, M. (2012). Refining the theory of basic individual values. Journal of Personality and Social Psychology, 103(4), 663-688. https://doi.org/10.1037/a0029393

Tarhan, N. (2020). Z kuşağ l kayıp kuşak olmasin. Erişim Adresi: https://uskudar.edu.tr/tr/icerik/5466/prof-dr-nevzat-tarhan-z-kusagikayip-kusak-olmasin

Toruntay, H. (2011). Takım rolleri çalışması: X ve Y kuşağı üzerinde karşılaştırmalı bir araştırma. Yayımlanmamış Yüksek Lisans Tezi, İstanbul Üniversitesi, İstanbul.

Tutgun-Ünal, A. ve Deniz, L. (2020). Sosyal medya kuşaklarının sosyal medya kullanım seviyeleri ve tercihleri. OPUS-Uluslararası Toplum Araştırmaları Dergisi, 15(22), 125-144.

Türk Medeni Kanunu (2001). Türk Medeni Kanunu. Erişim Adresi: https://www.mevzuat.gov.tr/MevzuatMetin/1.5.4721.pdf

Yıldırım Becerikli, S. (2013). Kuşaklararası iletişim farklılı̆̆ı: Bilim teknoloji ve yenilik haberleri üzerinden bir odak grup çalışması. Selçuk İletişim, $8(1), 5-18$. 


\section{Kaynakça Bilgisi / Citation Information}

Çelik, A. R., Asqarova, S. ve Tutgun Ünal, A. (2021). Üniversite öğrencilerinin eş seçim tutumlarında değer yönelimlerinin etkileri. OPUS-Uluslararası Toplum Araştırmaları Dergisi, 18(38), 5042-5070. DOI: 10.26466/opus.883241 